\title{
OBVIOUS AND HIDDEN FEATURES OF CORPORATE DEFAULT IN BANKRUPTCY MODELS
}

\author{
Michal KUBĚNKA*, Renáta MYŠKOVÁ \\ Institute of Business Economics and Management, Faculty of Economics and Administration, \\ University of Pardubice, Studentská 95, 532 10, Pardubice, Czech Republic
}

Received 17 December 2018; accepted 11 January 2019

\begin{abstract}
The aim of this article is to prove the key role of the structure of the research sample used for accuracy determining on the accuracy of bankruptcy models. The creators of these models report the accuracy usually in the range of 60 to $90 \%$. The authors of this article claim that these values are inaccurate and misleading. The real I. type error should be detected on a sample where obvious features of financial default were eliminated. The research tested more than 1200 of thriving businesses and also 270 businesses in future bankruptcy. The research has determined real current accuracy of selected three bankruptcy models on the standard sample of Czech businesses amounting $67.77 \%, 62.27 \%$ and $74.36 \%$. This confirmed hypothesis no. 1 , which says that actual accuracy of bankruptcy model is lower than original accuracy indicated by model makers. An accuracy of $58.70 \%, 61.59 \%$ and $65.94 \%$ was measured on a sample where businesses with obvious features of financial distress were eliminated. Due to the modification of the test sample, the order of accuracy has changed. This confirmed hypothesis no. 2. The Index of Karas and Reznakova reached the highest overall accuracy of $80.31 \%$ including incorrect prediction of bankruptcy also.
\end{abstract}

Keywords: corporate default, bankrupt models, financial distress, prediction accuracy

JEL Classification: C52, C53, G32, M21.

\section{Introduction}

The financial default can be considered both in a practical and legislative plane. Statistical data from separate countries represent a number of insolvency proposals, however, their comparability can be weakened due to different legislation in particular countries.

The legislation on insolvency proceedings in the Czech Republic is governed by Act no. 182/2006 Coll., on Bankruptcy and Methods of Its Settlement, as amended (hereinafter the Insolvency Act). Insolvency Act was enacted on 1st January 2008 and replaced the previous regulation (Act no. 328/1991 Coll.). The solution of insolvency by means of legal proceedings is intended to match up the property relations of the debtor and creditors. Ac-

${ }^{\star}$ Corresponding author. E-mail: michal.kubenka@upce.cz 
cording to the Insolvency Act $(\$ 3)$, a debtor is bankrupt if there are more creditors, repayable obligations are older than 30 days, and the debtor is unable to satisfy the financial obligations. The Insolvency Act specifies four methods of the solution of default, namely bankruptcy, reorganization, discharge from debts, and special methods of the solution of default for certain types of cases. None from these methods ensures immediate and full satisfaction of creditors. A question is all the more suggested itself how to ensure that the creditor timely recognized financial problems of its business partner and prevent, thus, a situation when it must participate in insolvency proceedings.

The following Figure 1 shows that there are tens of thousands of insolvency proposals each year. For example, according to the Czech Statistical Office (CZSO, 2018), there were 1.475 million active businesses in the Czech Republic in 2017, 1.373 million inactive and 2.849 million enterprises in total. Thus, in 2017, the number of insolvency proposals represents $0.81 \%$ of all enterprises and $1.57 \%$ of active enterprises in the Czech Republic. This means that every sixty-fourth active business was in financial trouble.

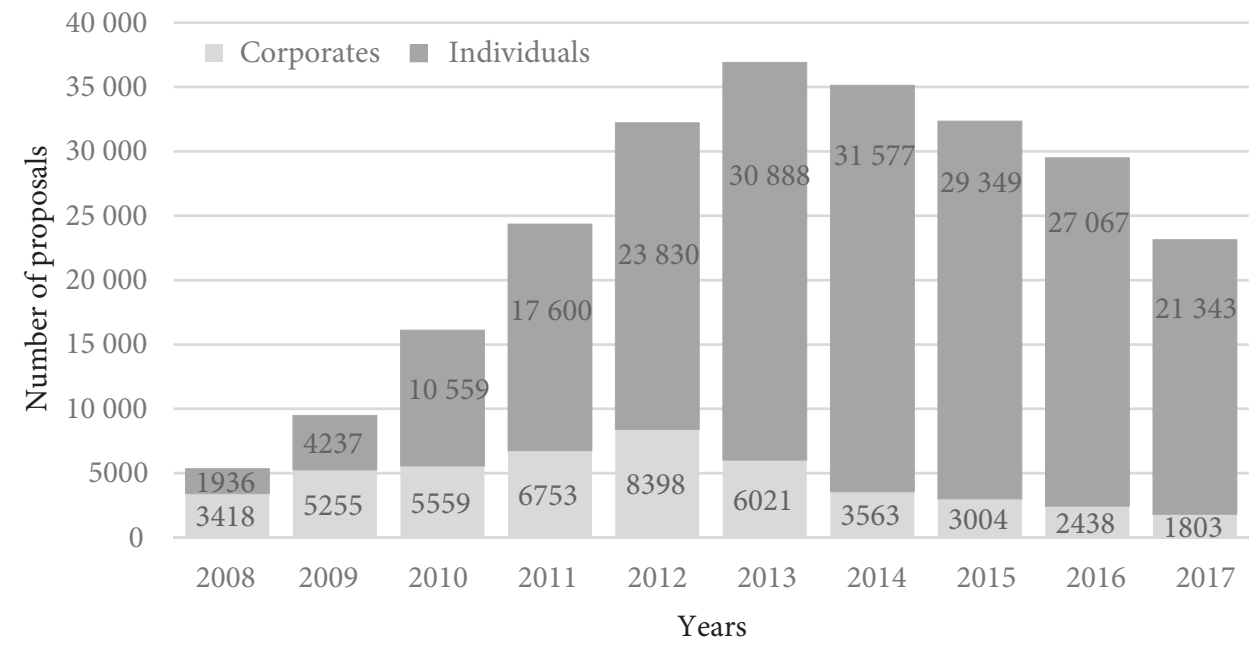

Figure 1. Insolvency in 2008-2017 (source: CreditReform, 2014, 2016, 2018b)

According to Creditreform (2018a), Europe was economically successful in 2017, and it impacted the number of insolvencies, which was in the given year lower in comparison with the last year. Concretely, in Western Europe (including Norway and Switzerland) between 2016 and 2017, a decline of insolvencies by $4.2 \%$ was registered (i.e. from about 171,000 of entrepreneurial entities in 2016). In total, 164,000 of company insolvencies was registered in 2017. The number of insolvencies also declined in 2017 in Central and East Europe. Compared with the last year, it was a decline by 12.8 percent to 87,000 cases in total.

The highest number of insolvencies in West Europe belongs traditionally to France $(54,470$ in 2017; 57,953 in 2016 and 61,429 in 2015); however, during last three years, the number of insolvencies is being gradually decreasing, in the last two tracked years by $6 \%$. Germany is - with a large gap - in second place with a number of 20,140 insolvencies in $2017(21,560$ in 2016; 23,180 in 2015). The third place belongs to the United Kingdom with the maximum 
insolvency of 18,000 in 2017 within the period of 2015 to 2017. The remaining countries of West Europe fluctuate in 2017 approximately just in thousands of insolvency cases annually. Ireland had just 874 insolvency cases in 2017, which is the minimum in West Europe.

Based on the Eurostat statistics (EUROSTAT, 2018), the number of insolvencies declined between 2016 and 2017 in Central Europe the most in Croatia $(-42.9 \%$, which could be caused, among others, by new legislation), in the Czech Republic ( $-26 \%$, new legislation as well) and in Macedonia (-22\%). The highest number of corporate insolvencies in West Europe has Luxembourg (2.69\%), Denmark (2.45\%), Switzerland (1.97\%), Belgium (1.52\%) and Francie (1.34\%).

CreditReform (2018a) claims that insolvencies usually represent only a very small part of all business liquidations and that small firms in financial difficulties generally simply wind up their operations without any insolvency proceedings. They are then merely erased from commercial registers. In 2017 there were 2.2 million closures in Western and Eastern Europe, out of which 620,000 closures happened in Eastern Europe).

In spite of the decline of insolvency proposals in a number of countries, the decline of insolvency proposals is high (1.57\% of active enterprises in the Czech Republic in 2017).

Thus, prevention of bankruptcy in one's own business or that of a business partner is essential. Frequently, bankruptcy might be avoided or, at least, losses may be minimized if the incoming bankruptcy is identified in advance. A business strategy orientation for a company is indispensable (Mohelska \& Sokolova, 2016).

It is clear that a financially healthy enterprise is getting gradually into an onerous financial situation. It is gradually losing its job orders, its turnover is decreasing, and, consequently, its profitability is dropping off, and in the course of time it is then getting into financial losses. This is followed by a growth of indebtedness, which will switch up to the financial insolvency. Therefore, bankruptcy models operate with the assumption that the symptoms of bankruptcy had been apparent long enough before the enterprise went eventually bankrupt. Thus, it seems, an imminent bankruptcy could be averted by timely prediction of financial bankruptcy.

For this purpose, the authors focus on assessing the aspects that may signal future financial distress of enterprises. The subject of the research is bankruptcy models presented in the economic theory for the ability to predict bankruptcy and the assessment of their accuracy depending on the structure of the sample of enterprises surveyed. Selected models are tested on the empirical data of enterprises operating in the manufacturing industry. Variations in accuracy are calculated based on the structure of the test sample, and their significance is assessed by the confidence interval.

The structure of the contribution is as follows. The first section provides the literature related to the topic. Next, the research goal and hypothesis are defined. Section 3 includes a description of the research sample, data processing and hypothesis validation methodology. The results and discussions are outlined in section 4 . The final section presents our conclusions and directions for future research. 


\section{Literature review}

As early as in the mid-20th century, several authors attempted to find a simple and yet accurate model that would determine a future financial decline. First of all, it has been tested whether just one ratio indicator from the field of profitability, turnover of asset, liquidity and cash flow can be enough. The researches, unfortunately, showed that one indicator will not be able to sufficiently evaluate the financial stability of so complex entity as an enterprise is (FitzPatrick, 1932; Smith \& Winakor, 1935). That's why specialists were consequently focusing on a combination of some ratio indicators which would complexly assess an enterprise situation and could thus better predicate its future prosperity or bankruptcy.

The breakthrough came in 1968 with the Altman Z-score (Altman, 1968). Using multivariate analysis, prof. Altman created a credit-strength test for predicting bankruptcy. The Altman Z-score uses financial data contained in accounting books and is based on five financial ratios. Thereupon, other authors followed with their models, all of them utilizing mathematical and statistical methods.

J. A. Ohlson counts among the most well-known followers. In 1980, he was the first who proposed a logit linear probability model (Ohlson, 1980). In 1985, Christine V. Zavgren's logit model was capable of obtaining independent variables by using factor analysis (Zavgren, 1985). Consequentially, with the development of artificial intelligence, new predictive models were based on neural networks (NN), e.g. models of Tam and Kiang (Tam, 1991; Tam \& Kiang, 1992).

There have been many attempts to compare the usefulness of the particular methods (MDA vs. Logit vs. NN) used to create predictive models. As an example, we can mention the research of Korol (2013), who created predictive models based on statistical and soft computing methods, and consequently compared the effectiveness of discriminant analysis, decision trees, and artificial neural networks models. An explanatory value of particular bankruptcy model may be different as is illustrated by Arroyave (2018) while testing the following models: Z-Altman model, Korol's model and Prusak's P2 model.

The results show NN as the most suitable method as proven by (Pendharkar, 2005; Liang \& Wu, 2005; Rafiei, Manzari, \& Bostanian, 2011). The weak point of NNs, however, is their limited usability by the expert public, because a special software is necessary to use them, while the bankruptcy models such as Z'score, $\mathrm{P}^{\prime}$ model, or Index of Karas and Režňáková (formula 1 to 3 ) are shareware, and their application is relatively easy for analysts.

After the passage to the market economy (the '90s of the 20th century), the bankruptcy models also started to emerge in the Czech and Slovak Republics in order to predict business bankruptcy. These models were created in order to reflect the market specificity of these countries. The first such a model was the index IN95 (Neumaierová \& Neumaier, 2002), originally conceived as a creditor's model. The authors later redesigned their model from the point of view of the owner of the enterprise, and thus created the index IN99. In 2001 they created the model IN01 (in 2005 updated version IN05) that connected properties of both of the previous models, i.e. it predicts bankruptcy as well as prosperity based on the positive economic value added (Neumaierová, 2005). The following models can be ranked among more known and more accurate ones which originated after the 2008 economic cri- 
sis P'model (Delina \& Packová, 2013) and the bankruptcy Index of Karas and Režňáková (hereinafter referred to as the $\mathrm{I}_{\mathrm{KR}}$ ) (Karas \& Režňáková, 2014) and specialized bankruptcy model made by Slavíček and Kuběnka (2016) for companies operating in the construction sector in the Czech Republic with model accuracy of $94 \%$. The authors of model P' put the bankruptcy prediction return at $71.84 \%$. The authors of the $\mathrm{I}_{\mathrm{KR}}$ model determine the model accuracy at $91.71 \%$ (calculated as the weighted average of TP and TF prediction). A number of publications are focused on current accuracy measurement and accuracy improvement of bankruptcy prediction in Czech and Slovak Republic (e. g. Gavurova, Janke, Packova, \& Pridavok, 2017a; Gavurova, Packova, Misankova, \& Smrcka, 2017b; Hájek, Olej, \& Myskova, 2014; Kuběnka, 2015).

A lot of researches and authors specify that it is suitable to monitor both financial and non-financial indicators for the measurement of the enterprise's overall performance (Dobrovic, Lambovska, Gallo, \& Timkova, 2018; Alaka et al., 2017; Zizlavsky, 2016). In connection with the assessment of the enterprise's performance, Hornungová (2017) emphasizes the importance of knowledge, and writes that it is sometimes considered as a fifth production factor, and it is, thus, necessary to consider it while evaluating the enterprise's results.

As key quantitative factors of financial stability are usually stated cash flow, liquidity, profitability, leverage (Kuběnka, 2015; Alaka et al., 2017).

Key qualitative factors are undoubtedly management characteristics, owners, internal strategy, macroeconomic environment. The assessment of these and other qualitative factors may sketch the actual financial position of the enterprise and may help to predicate more accurately the future development, including on-coming insolvency. Unfortunately, information on a number of these qualitative factors is hardly accessible or absolutely unavailable for business partners or another stakeholder.

Bowen, Davis, and Matsumoto (2005) also draw attention to a danger related to a purposeful falsification of information provided by managers, when they strive to present mainly positive aspects of the enterprise activities. In general, however, additional information is considered to be a contribution for stakeholders, although these data have social or psychological context (Merkl-Davies, Brennan, \& McLeay, 2011).

For the above-mentioned reasons, the qualitative evaluation of a selected entity based on the account statements analysis is primary for analysts. The proper application of the bankruptcy models, however, has to be performed methodically correctly.

Let's suppose that the bankruptcy model is the most accurate when applied to the region (country) of its origin (due to the differences of accounting methods, market environment, etc.). Let's also suppose that there are no significant differences between the market environment in the Czech and the Slovak Republics. We shall test two of the above mentioned models, the economic crisis P' model and the bankruptcy index $\mathrm{I}_{\mathrm{KR}}$. For comparison, we have decided to include one of Altman's Z score models as they are still widely used. All three models were applied to a sample of Czech and Slovak businesses with and without apparent signs of financial distress, and the results were compared to determine the accuracy of particular models. 


\section{Research objective and hypothesis}

This research wants to answer the question whether a research sample on which the accuracy of the model is validated does not affect the resulting accuracy of the model by its structure. The aim of this article is to prove the key role of the structure of the research sample used for accuracy determining on accuracy of bankruptcy models. The research will determine the extent of change of the specified accuracy when eliminating the most obvious signs of bankruptcy. The survey focuses on the impact of a possible change of the type I error on the overall accuracy of the selected models with consistent type II error.

In order to achieve the objective set out these hypotheses can be posed:

- Hypothesis no. 1: Actual accuracy of bankruptcy model is lower than original accuracy indicated by model makers.

- Hypothesis no. 2: Accuracy of bankruptcy model is reduced if obvious corporate default features are eliminated.

\section{Data processing \& methodology}

To test these hypotheses, the following research methodology was used: 1 . definition of the research sample; 2. selection of models for testing; 3. description of the chosen method of measuring accuracy. See more as follows.

\subsection{Analysed set of businesses and data processing}

Overall, 273 bankrupt businesses and 1224 non-bankrupt Czech businesses operating in the manufacturing industry were used in the tested sample. The non-bankrupt group showed no negative signs (insolvency, failure, extinction, execution, negative shareholders' capital) in the year 2012 .

This sample was used for finding current accuracy of selected tested model (test no. 1). It was crucial that financial statements of the bankrupt enterprises in our sample had to be available both for the year of bankruptcy (2013) and for the previous year (2012), to enable monitoring of a possible occurrence of negative events in previous years too.

Data for the year 2012 and 2013 was used because in the following years it was not possible to obtain enough information to ensure representativeness of the sample.

Generally, negative events include bankruptcy, execution, insolvency, claim, enforced execution, liquidation, extinction, negative equity, VAT unreliability or loss for several consecutive years. In particular, in the tested sample, the most obvious indicators of bankruptcy were identified as loss for several consecutive years, negative own equity, and negative economic performance.

As we attempted to eliminate the most obvious signs of bankruptcy mentioned above, 135 companies were excluded out of the original 273 (see Table 1). The selected predictive models were applied to the remaining 138 companies, and the accuracy of prediction was evaluated (test no. 2). 
Table 1. Frequency of negative events (source: authors)

\begin{tabular}{|l|c|c|}
\hline \multicolumn{1}{|c|}{ Negative events } & Absolutely & Relatively \\
\hline Negative equity & 82 & $61 \%$ \\
\hline Loss & 63 & $47 \%$ \\
\hline Negative equity \& Loss & 41 & $30 \%$ \\
\hline Loss for several consecutive years & 34 & $25 \%$ \\
\hline Total & 135 & $100 \%$ \\
\hline
\end{tabular}

Data were provided from the database of economic entities Bisnode MagnusWeb (2018). The following part will detail the calculation methodology. The items Balance Sheet (BS) and the items Profit / Loss Statement shall be processed as follows:

a) $X_{1}\left(\mathrm{I}_{\mathrm{KR}}\right)$ : Total assets of EUR (exchange rate at $27 \mathrm{CZK} / \mathrm{EUR}$ ).

b) $X_{2}\left(\mathrm{I}_{\mathrm{KR}}\right)$ : Sales $=$ Sold Goods + Sold products and services.

c) $X_{1}\left(\mathrm{P}^{\prime}\right.$ model $)$ : Financial property $=$ Long term financial property + Short term financial property.

d) $X_{1}\left(\mathrm{P}^{\prime}\right.$ model): Operating expenses = sum of cost items from A. to I. (of P/L Statement).

e) $A_{2}\left(\mathrm{P}^{\prime}\right.$ model \& $\mathrm{Z}^{\prime}$ score $)$ : Retained earnings = Funds from earnings + Retained earnings.

f) $A_{3}\left(\mathrm{P}^{\prime}\right.$ model $\& \mathrm{Z}^{\prime}$ score $):$ EBIT $={ }^{* * *} \mathrm{EAT}+\mathrm{Q} .+\mathrm{S} .+\mathrm{N}$.

g) $B_{1}\left(\mathrm{P}^{\prime}\right.$ model): Cash flow calculation: ${ }^{*}$ Operating profit + Depreciations - Change in reserves.

h) $B_{4}\left(\mathrm{P}^{\prime}\right.$ model): Total Operating Revenue includes Revenues from no. I. to no. IV.

\subsection{Tested bankrupt models}

One American, one Czech and one Slovak bankruptcy model were selected.

\section{Altman's Z'score}

The original Altman's Z score of 1968 was designed for publicly traded joint stock companies. In the course of time, Altman has concluded that such a model has limited applicability, because only part of enterprises is founded as a joint stock company and only part of them is at the same time are tradable at stock exchange. This has contributed to the publication in 1983 of his next bankruptcy model Z'score (1983) destined for public limited companies and non-publicly traded shares. This newer model has not already worked with a market value of the equity but with the book value of the equity. The author specifies that model accuracy is $82 \%$, which corresponds to the error of type I. at the amount of $18 \%$. Altman's model (Altman, 1993) has this formula:

$$
Z^{\prime} \text { score }=0.717 X_{1}+0.847 X_{2}+3.107 X_{3}+0.420 X_{4}+0.998 X_{5},
$$

where: $T A-$ total assets; $X_{1}=\frac{\text { working capital }}{\mathrm{TA}} ; X_{2}=\frac{\text { retained earnings }}{\mathrm{TA}} ; X_{3}=\frac{\mathrm{EBIT}}{\mathrm{TA}}$; $X_{4}=\frac{\text { equity }}{\text { TA }} ; X_{5}=\frac{\text { sales }}{\text { TA }}$. 
Score of more than 2.90 means financial stability, score below 1.23 means insolvency / corporate default. Values from 1.23 to 2.90 are the grey zone (indecision zone).

\section{Index of Karas and Režňáková}

This bankruptcy model is interesting because it contains less ratio indicators than most of known bankruptcy models, as well as because it contains a component in its absolute value $\left(X_{1}\right)$ that represents total assets in EUR. The second one $\left(X_{2}\right)$ is the assets turnover (sales/total assets) and the third one $\left(X_{3}\right)$ compares quick assets with sales ((current assets - reserves)/ sales). The model was based on a sample of 880 financially stable and 628 bankrupted companies (Karas \& Režňáková, 2014). Data was drawn from account books from the period 2007 to 2012. All 1508 companies belonged to the processing industry (NACE rev. 2, section C: Manufacturing). The model has the following form (Karas \& Režňáková, 2014):

$$
\begin{gathered}
I_{K R}=1.841 \times \frac{\left(X_{1}+16783.91\right)^{0.02941}-1}{0.02941}+1.112 \times \frac{\left(X_{2}+1\right)^{-0.35627}-1}{0.35627}+13.55 \\
\times \frac{\left(X_{3}+1.112\right)^{-2.97955}}{2.97955}-17.319,
\end{gathered}
$$

where: $X_{1}$ - value of total assets (EUR); $X_{2}$ - turnover of total assets; $X_{3}$ - ratio between current assets and sales.

Surprisingly, $\mathrm{I}_{\mathrm{KR}}$ achieves a relatively high level of accuracy, although it does not include the grey zone. $\mathrm{I}_{\mathrm{KR}}$ value $>0$ indicates a financially healthy company and $\mathrm{I}_{\mathrm{KR}}$ value $<0$ indicates a risk of bankruptcy. Accuracy of model see Table 2.

Table 2. Results of tested model $\mathrm{I}_{\mathrm{KR}} 2013$

\begin{tabular}{|c|c|c|c|c|c|}
\hline Time & Active & Bankrupted & Total $^{\star}$ & Error of I. kind & Error of II. kind \\
\hline 1 & 97.89 & 69.91 & 91.71 & 30.09 & 2.11 \\
\hline 2 & 95.60 & 65.56 & 89.65 & 34.11 & 4.29 \\
\hline 3 & 94.38 & 65.23 & 89.19 & 34.38 & 5.50 \\
\hline 4 & 93.04 & 65.42 & 88.56 & 34.11 & 6.83 \\
\hline 5 & 91.47 & 61.18 & 87.81 & 38.82 & 8.39 \\
\hline
\end{tabular}

Note: ${ }^{*}$ weighted average of accuracy (source: Karas \& Režňáková, 2014).

\section{$\mathrm{P}^{\prime}$ model}

Whreating their model, Delina and Packová (2013) were influenced by three existing models. Two of them are widely used Altman Z'score (purely bankruptcy model) and Ind of creditworthiness. The third model, the IN05, is used mainly in the Czech Republic for which specific environment it was also created. The IN05 differs from traditional models as it also deals with the prediction of added economic value.

Delina and Packová analysed 1560 accounting statements of Slovak companies from the period 1993-2007. Out of the total, there were 1457 active companies (93.40\% of the whole sample) and 103 bankrupt enterprises (6.60\%). The field of the analysed business is now 
specified, the sample is merely divided into production companies (36.60\%), business companies (25.71\%) and service companies (37.69\%). Z'score, Creditworthiness Index, and IN05 were tested, and all of them demonstrated a low level of prediction capability. Accuracy was calculated in a different way as conditioned probability $\pi_{j}$ and probability $p_{j}$.

$$
\begin{aligned}
& \pi_{j}=\mathrm{TP}_{\mathrm{j}} /\left(\mathrm{TP}_{\mathrm{j}}+\mathrm{FP}_{\mathrm{j}}\right) ; \\
& \mathrm{p}_{\mathrm{j}}=\mathrm{TP}_{\mathrm{j}} /\left(\mathrm{TP}_{\mathrm{j}}+\mathrm{FN}_{\mathrm{j}}\right),
\end{aligned}
$$

$\mathrm{TP}_{\mathrm{j}}$ represents the number of businesses that have actually gone bankrupt and which model has been classified as bankrupt (exact prediction of bankruptcy). Similarly, $\mathrm{FP}_{\mathrm{j}}$ represents the number of companies that did not actually enter bankruptcy, but the model has classified them as bankrupt (incorrect prediction of bankruptcy). The $\mathrm{FN}_{\mathrm{j}}$ pivot table variable is for companies that went bankrupt but classified by the model as financially sound. $\mathrm{TN}_{\mathrm{j}}$ represents the number of businesses that did not go bankrupt and also the model has classified these businesses as financially sound.

Table 3. Pivot Table for classification of test sample (source: Delina \& Packová, 2013)

\begin{tabular}{|c|c|c|}
\hline & $\theta(d i, c j)=$ true & $\theta(d i, c j)=$ false \\
\hline$\theta^{\wedge}(d i, c j)=$ true & $T P_{j}$ & $F P_{j}$ \\
\hline$\theta^{\wedge}(d i, c j)=$ false & $T N_{j}$ & $F N_{j}$ \\
\hline
\end{tabular}

Delina and Packová (2013) used Table 3 as Pivot Table for classification of test sample of businesses. Their assessment of selected models is based on this calculation methodology. The test results are in Table 4.

Table 4. Validation of Models - Results (source: Delina \& Packová, 2013)

\begin{tabular}{|l|c|c|c|c|}
\hline \multicolumn{1}{|c|}{ Models } & $\begin{array}{c}\text { No. of bankrupt } \\
\text { prediction }\end{array}$ & False prediction & $\mathrm{p}_{j}$ & $\pi_{j}$ \\
\hline \multirow{2}{*}{ Altman } & \multirow{2}{*}{428} & 375 & \multicolumn{2}{|c|}{53} \\
\cline { 2 - 5 } & \multirow{2}{*}{ Prosperity Index } & $87.62 \%$ & $12.38 \%$ & $51.46 \%$ \\
\hline \multirow{2}{*}{ IN05 } & \multirow{2}{*}{521} & 213 & \multicolumn{3}{|c|}{60} \\
\cline { 2 - 5 } & & $78.02 \%$ & $21.98 \%$ & $58.25 \%$ \\
\cline { 2 - 5 } & & 445 & $14.59 \%$ & $73.79 \%$ \\
\hline
\end{tabular}

Note: ${ }^{\star}$ created by Beerman (1976).

This is why Delina and Packová (2013) proposed their own predictive model. It uses not only ration indexes (as the existing models Z score, Creditworthiness Index, and IN05) but also regression analysis. Thus, $\mathrm{P}^{\prime}$ model was created:

$$
\begin{aligned}
& P^{\prime}=2.86-0.0001278 X_{1}+0.04851 A_{2}+0.2136 A_{3}-0.000071 A_{4}+0.0001068 B_{1} \\
& -0.0006116 B_{4},
\end{aligned}
$$


where: $X_{1}=\frac{\text { Financial assets }- \text { short }- \text { term liabilities }}{\text { Operating expenses }- \text { depreciations }} ; \quad A_{2}=\frac{\text { Retained Earnings }}{\text { Total Assets }}$;

$A_{3}=\frac{E B I T}{\text { Total Assets }} ; \quad A_{4}=\frac{\text { Registred capital }}{\text { Long }- \text { term }+ \text { short }- \text { term liabilities }} ; \quad B_{1}=\frac{\text { Cash flow }}{\text { Total liabilities }} ;$

$B_{4}=\frac{\text { Earnings before taxes }}{\text { Total operating revenue }}$.

$\mathrm{P}^{\prime}$ model does not include the "grey zone". The critical value the company classification is 2,856 . When $\mathrm{P}^{\prime}<2.856$ the company is in the risk of going bankrupt, $\mathrm{P}^{\prime}$ value $\geq 2.856$ indicates a financially healthy company with a low risk of bankruptcy. The authors of $\mathrm{P}^{\prime}$ model report the accuracy $\left(\pi_{\mathfrak{j}}\right)$ of their model as $71.84 \%$.

\subsection{Methodology of predictive power quantification}

The way of the evaluation methodology of models accuracy draws inspiration from E. Altman (1968) (the forefather of multiple-criteria models of bankruptcy prediction), and also from contemporary authors as Berzkalne and Zelgalve (2013) or Huijuan (2015).

Table 5. Accuracy-matrix

\begin{tabular}{|l|c|c|}
\hline \multirow{2}{*}{ Fact } & \multicolumn{2}{|c|}{ Prediction } \\
\cline { 2 - 3 } & Bankrupt & Non-bankrupt \\
\hline Bankrupt & $T P$ & $\alpha$ \\
\hline Non-bankrupt & $\beta$ & $T N$ \\
\hline
\end{tabular}

Notes: TP - number of correct predictions of future bankrupt; TN - number of correct predictions of future non-bankrupt; $\alpha$ - number of bankruptcy enterprises classified as non-bankrupt (type I error); $\beta$ - number of non-bankruptcy enterprises classified as bankrupted (type II error) (source: authors).

Accy opt prediction (ABP in \%) for bankrupt companies can then be expressed as follows:

$$
A B P=\frac{T P_{1}}{T P_{1}+\alpha} \times 100 .
$$

Accuracy of non-bankrupt prediction (ANP in \%) for non-bankrupt companies can then be expressed as follows:

$$
\begin{gathered}
A N P=\frac{T N_{2}}{T N_{2}+\beta} \times 100 ; \\
\text { Total accuracy }(T A)=\frac{A B P+A N P}{2} .
\end{gathered}
$$




\section{Results \& discussion}

In the test no. 1 we applied the three predictive models to the whole original research sample of 273 enterprises in bankruptcy. $\mathrm{P}^{\prime}$ model evaluated correctly 203 enterprises as bankrupt, which is $74.36 \%$ of the sample. Thus, $\mathrm{P}^{\prime}$ model proved to be the most successful model in our research. Removing enterprises with apparent signs of bankruptcy from the analysed sample reduced the model's accuracy to $67.77 \%$, which is a difference of $6.59 \%$.

The officially claimed success rate of $Z^{\prime}$ score $(82.00 \%)$ was not confirmed in our research, as it only evaluated $67.77 \%$ (185 enterprises) in bankruptcy. The least successful was the $\mathrm{I}_{\mathrm{KR}}$ model, where the authors claim accuracy of $69.91 \%$ while our test no. 1 indicates accuracy of $62.27 \%$, i.e. only 170 enterprises classified as bankrupt. The predictive $\mathrm{P}^{\prime}$ model in our tests correctly ranked $74.36 \%$, Z'score model ranked $67.77 \%$ and predictive model $\mathrm{I}_{\mathrm{KR}}$ ranked $62.27 \%$.

Pacakova, Pardelova, Sodomova, and Soltes (2003) determine the reliability interval for these results as follows.

$$
P\left(p-z_{1-\frac{\alpha}{2}} \cdot \sqrt{\frac{p(1-p)}{n}}<\pi<p+z_{1-\frac{\alpha}{2}} \cdot \sqrt{\frac{p(1-p)}{n}}\right)=1-\alpha,
$$

where: $p$ - found current accuracy; $n$ - the size of the base $\pi$ (number of enterprises in sample); $\alpha$ - a significance level of 0.05 .

Table 6 compares accuracy of predictive models originally stated by their authors, current accuracy checked in our test no. 1, confidence interval of current accuracy and accuracy with eliminated apparent signs checked in test no. 2.

Table 6. Accuracy with and without taking into account apparent signs (source: authors)

\begin{tabular}{|l|c|c|c|c|}
\hline \multicolumn{1}{|c|}{ Model } & $\begin{array}{c}\text { Original } \\
\text { accuracy }\end{array}$ & $\begin{array}{c}\text { Current } \\
\text { accuracy }\end{array}$ & $\begin{array}{c}\text { Interval of } \\
\text { confidence }\end{array}$ & $\begin{array}{c}\text { Accuracy without } \\
\text { apparent signs }\end{array}$ \\
\hline $\mathrm{Z}^{\prime}$ 'score & $82.00 \%$ & $67.77 \%$ & $62.23 \%$ to $73.31 \%$ & $58.70 \%$ \\
\hline $\mathrm{I}_{\mathrm{KR}}$ & $69.91 \%$ & $62.27 \%$ & $56.52 \%$ to $68.02 \%$ & $61.59 \%$ \\
\hline $\mathrm{P}^{\prime}$ 'model & $71.84 \%$ & $74.36 \%$ & $69.18 \%$ to $79.54 \%$ & $67.77 \%$ \\
\hline
\end{tabular}

After excluding companies with apparent signs of bankruptcy, accuracy without apparent signs was determined on a reduced sample of 138 companies. The resulting order of accuracy changes as follows:

- P'model with accuracy of $67.77 \%$;

- $\mathrm{I}_{\mathrm{KR}}$ with lower accuracy of $61.59 \%$;

- Z'score with lowest accuracy of $58.70 \%$.

In the test no. 2 (without apparent signs of bankruptcy), the accuracy of $Z$ 'score and $\mathrm{P}^{\prime}$ model is out of the confidence interval of accuracy checked in test no. 1 . Thus, it can be claimed that usage of visible features of bankruptcy leads to significant distortions in the accuracy of predictive models. It was confirmed with statistical significance for $Z$ 'score and $\mathrm{P}^{\prime}$ model. Also $\mathrm{I}_{\mathrm{KR}}$ success rate of prediction has fallen (from $62.27 \%$ to $61.59 \%$ ) but this was not confirmed statistically significant. Graphically presented in Figure 2. 


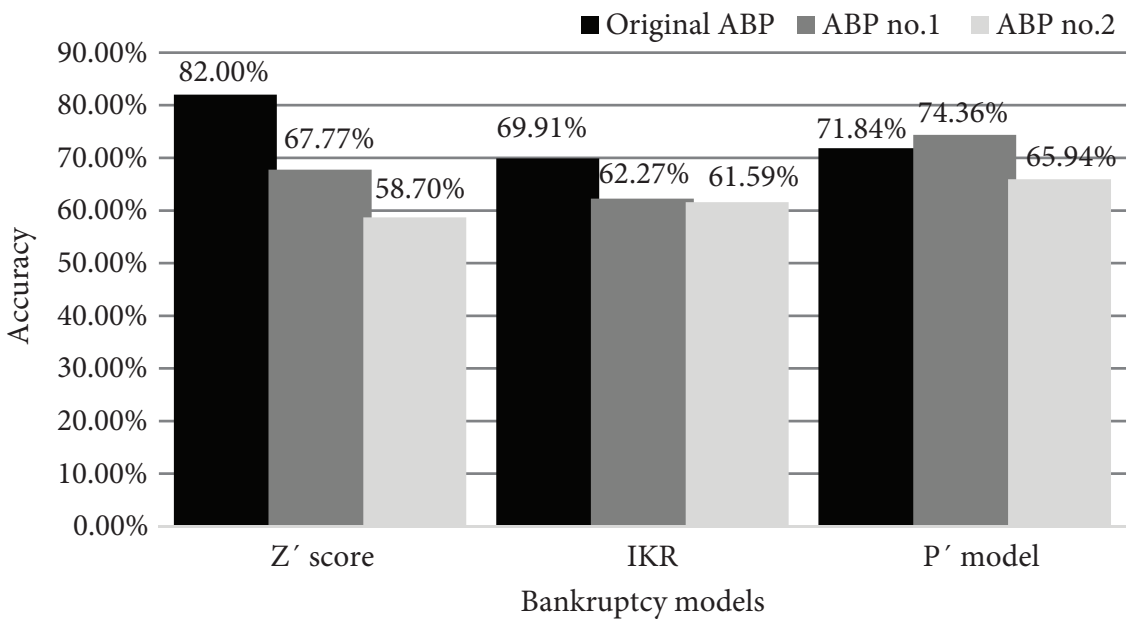

Figure 2. Accuracy of models in failure prediction (source: authors)

1220 financially stable businesses were tested to see whether tested models designate them as financially sound (see Table 5 , TN position in matrix - the number of correct predictions of future non-bankruptcies). Clearly the most successful in this area was the $\mathrm{I}_{\mathrm{KR}}$ model, which correctly identified $99.02 \%$ of the businesses as financially sound.

$\mathrm{P}^{\prime}$ model ranked second with $93.28 \%$ of the correct ratings. Altman $\mathrm{Z}^{\prime}$ score is currently unusable in the Czech Republic. The result of $26.64 \%$ of correct predictions is insufficient. The reason for this poor result is not that the rest of the sample was classified as bankrupt, but that whole $63 \%$ of the sample ranked in the grey zone where it could not decide how to classify them. This calculation was based on formula (7). Subsequently, it was necessary to evaluate the current overall accuracy of the tested models according to formula (8). The results are shown in Table 7 and graphically in Figure below.

Table 7. Total accuracy with and without apparent signs (source: authors)

\begin{tabular}{|l|c|c|c|c|c|c|}
\hline & Original ABP & ABP no.1 & ABP no.2 & ANP & TA no.1 & TA no.2 \\
\hline $\mathrm{Z}^{\prime}$ score & $82.00 \%$ & $67.77 \%$ & $58.70 \%$ & $26.64 \%$ & $47.21 \%$ & $42.67 \%$ \\
\hline $\mathrm{I}_{\text {KR }}$ & $69.91 \%$ & $62.27 \%$ & $61.59 \%$ & $99.02 \%$ & $80.65 \%$ & $80.31 \%$ \\
\hline P'model $^{\prime}$ & $71.84 \%$ & $74.36 \%$ & $65.94 \%$ & $93.28 \%$ & $83.82 \%$ & $79.61 \%$ \\
\hline
\end{tabular}

The overall accuracy of each model according to (8) shows that the most accurate $(83.82 \%$ TA no. 1) is the $\mathrm{P}^{\prime}$ model if the accuracy of the model is tested on a sample that includes enterprises with obvious signs of bankruptcy. The second place was $\mathrm{I}_{\mathrm{KR}}$ (80.65\% TA no. 1). The success of the prediction of the Z'score in the Czech Republic can be compared to coin flipping. The ranking of the first two bars changes after eliminating businesses with obvious features of bankruptcy changes.

The $\mathrm{I}_{\mathrm{KR}}$ model has the highest overall accuracy TA no. 2 (80.31\%) according to the calculation (8). This is largely due to the high accuracy of ANP (99.02\%) and the fact that the 


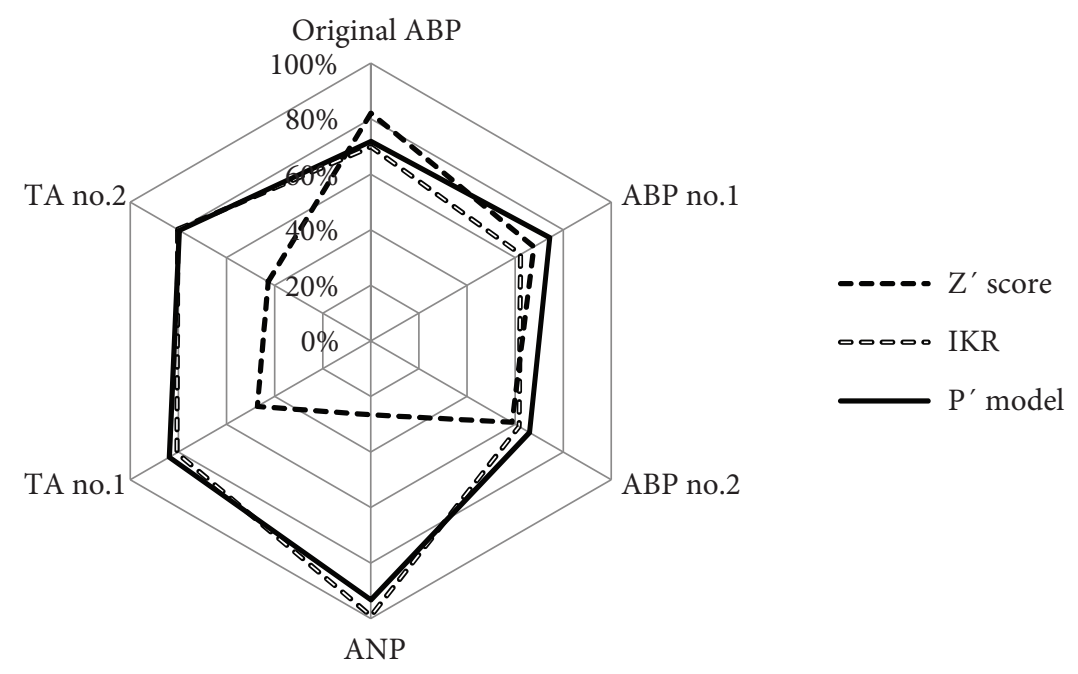

Figure 3. Success of business failure prediction (source: authors)

$\mathrm{ABP}$ has almost not changed itself after the elimination of the obvious features of bankruptcy in sample (ABP no. 1: $62.27 \%$ vs. ABP no. 2: $61.59 \%$ ).

The authors tested the assumption that the accuracy given by their creators currently does not correspond to reality (hypothesis no. 1). This fact was confirmed on a sample of 1497 enterprises in two of the three models tested. The main objective of this research was to show that a number of models are presented with a higher accuracy than their actual accuracy as a result of the inclusion of businesses with obvious features in tested sample. The authors assumed that after sample reduction their accuracy would be lower (hypothesis no. 2). This hypothesis was confirmed in all three cases and in two of them ( $Z^{\prime}$ score \& $\mathrm{P}^{\prime}$ model) with a statistical significance.

\section{Conclusions}

The article focuses on testing known bankruptcy models to determine their current accuracy. Typically, the business sector, the accounting system, the truthfulness and methods of accounting, the obsolescence of the model, the application in another state (different market environment), not taking into account changes in market prices of assets are usually considered as influences affecting the stated level of accuracy. There is also an ambiguously defined term "bankruptcy", "financial distress" or "failed", and the moment when the business officially obtains this attribute. In addition, when a model is used in another country, a business is flagged as bankrupt under the laws of the state in which the business is located. The survey was focused on the manufacturing industry and the models tested were also based on samples of businesses operating in the manufacturing industry. It strictly complied with the methodology of the original models for their application to Czech companies. This ensured conditions required for an objective investigation. The survey brought not only information on the current accuracy of the selected models, which is different to original accuracy (hy- 
pothesis no. 1 confirmed), but also confirmed the hypothesis that the test sample composition significantly influences the resulting accuracy of the bankruptcy models (hypothesis no. 2 confirmed). If we exclude businesses with obvious features of bankruptcy from the test, the survey is more objective. The authors of this research do not deny an opinion that qualitative information could help in the creation of a more complex view to the financial stability of the analysed enterprise. At the same time, however, it is necessary to take into consideration that information on the enterprise presented in public can be purposefully distorted, and information which has the highest explanatory ability is internal, and thus is unavailable in most of cases for external stakeholders and analysts.

This research has yielded results about new key factors of accuracy of bankrupt models in the Czech Republic however their comparability with other countries can be weakened due to a different legislation. The authors are aware that using relatively old data (due to their ready availability) may be a limitation of the research. However, the period when the data was acquired should not have a significant effect on verifying hypotheses and presented results. Future research possibilities in area of accuracy improvement the authors see in modification of approach to testing the predictors, while considering their significance as dependent on macroeconomic factors. Dynamic approach to predicting bankruptcy could be formulated by analysing the relationship between predictors and the key macro variables and by the utilisation of these relationships for prediction purposes.

\section{Contribution}

Both authors contributed equally in writing manuscript. Dr. Michal Kuběnka analysed and interpreted data. Dr. Renáta Myšková designed the scientific framework, processed data, set hypotheses.

\section{Disclosure statement}

The authors declare that they have no conflict of interest. No third party played a role in the conception and design of the work, or processing and interpreting data.

\section{References}

Act No. 182/2006. Coll., on bankruptcy and methods of its settlement. Czech Republic.

Act No. 328/1991. Coll., on bankruptcy and composition. Czech Republic.

Alaka, H. A., Oyedele, L. O., Owolabi, H. O., Oyedele, A. O., Akinade, O. O., Bilal, M., \& Ajayi, S. O. (2017). Critical factors for insolvency prediction: towards a theoretical model for the construction industry. International Journal of Construction Management, 17(1), 25-49. https://doi.org/10.1080/15623599.2016.1166546

Altman, E. (1968). Financial ratios, discriminant analysis and the prediction of corporate bankruptcy. Journal of Finance, 23(4), 589-609. https://doi.org/10.1111/j.1540-6261.1968.tb00843.x

Altman, E. I. (1993). Corporate financial distress and bankruptcy: A complete guide to predicting and avoiding distress and profiting from bankruptcy. New York: John Wiley and Sons Inc. 
Arroyave, J. (2018). A comparative analysis of the effectiveness of corporate bankruptcy prediction models based on financial ratios: Evidence from Colombia. Journal of International Studies, 11(1), 273-287. https://doi.org/10.14254/2071-8330.2018/11-1/21

Beerman, K. (1976). Possible ways to predict capital losses with annual financial statements (Working Paper). University of Düsseldorf.

Berzkalne, I., \& Zelgalve, E. (2013). Bankruptcy Prediction Models: A Comparative Study of the Baltic Listed Companies. Journal of Business Management, 7, 72-82.

Bisnode MagnusWeb. (2018). Comprehensive information on companies in the Czech Republic and the Slovak Republic. Bisnode. Retrieved from https://magnusweb.bisnode.cz/udss/htm/?utm referrer=http\%3A\%2F\%2Fwww.magnusweb.cz\%2F

Bowen, R. M., Davis, A. K., \& Matsumoto, D. A. (2005). Emphasis on pro forma versus GAAP earnings in quarterly press releases: Determinants, SEC intervention, and market reactions. The Accounting Review, 80(4), 1011-1038. https://doi.org/10.2308/accr.2005.80.4.1011

CreditReform. (2014). Vývoj insolvencí v České republice v roce 2013. Federation of Creditreform Associations. Retrieved from https://www.creditreform.cz/novinky-downloads/vyvoj-insolvenci-v-cr.html

CreditReform. (2016). Vývoj insolvencí v České republice v roce 2015. Federation of Creditreform Associations. Retrieved from https://www.creditreform.cz/novinky-downloads/vyvoj-insolvenci-v-cr.html

CreditReform. (2018a). Corporate insolvencies in Europe. Federation of Creditreform Associations. Retrieved from https://www.creditreform.cz/fileadmin/user_upload/CR-International/local_documents/cz/Presseartikel/analyse_EU-2017-18_english.pdf

CreditReform. (2018b). Vývoj insolvencí v České republice v roce 2017. Federation of Creditreform Associations. Retrieved from https://www.creditreform.cz/ novinky-downloads/vyvoj-insolvenci-v-cr.html

CZSO. (2018). Podíl aktivních a neaktivních ekonomických subjektů $v \check{C} R$ k 31. 12. 2017. Czech Statistical Office. Retrieved from https://www.czso.cz/csu/czso/cr_od_roku_1989_res

Delina, R., \& Packová, M. (2013). Prediction bankruptcy models validation in Slovak business environment. E\&M Economics and Management, 16(3), 101-112.

Dobrovic, J., Lambovska, M., Gallo, P., \& Timkova, V. (2018). Non-financial indicators and their importance in small and medium-sized enterprises. Journal of Competitiveness, 10(2), 41-55. https://doi.org/10.7441/joc.2018.02.03

EUROSTAT. (2018). Statistical office of the European Union. Retrieved from http://ec.europa.eu/eurostat/data/statistics-a-z/abc

FitzPatrick, P. (1932). A comparison of ratios of successful industrial enterprises with those of failed companies. The Certified Public Accountant, 6, 727-731.

Gavurova, B., Janke, F., Packova, M., \& Pridavok, M. (2017a). Analysis of impact of using the trend variables on bankruptcy prediction models performance. Ekonomicky casopis, 65(4), 370-383.

Gavurova, B., Packova, M., Misankova, M., \& Smrcka, L. (2017b). Predictive potential and risks of selected bankruptcy prediction models in the Slovak business environment. Journal of Business Economics and Management, 18(6), 1156-1173. https://doi.org/10.3846/16111699.2017.1400461

Hájek, P., Olej, V., \& Myskova, R. (2014). Forecasting corporate financial performance using sentiment in annual reports for stakeholders' decision-making. Technological and Economic Development of Economy, 20(4), 721-738. https://doi.org/10.3846/20294913.2014.979456

Hornungová, J. (2017). Nonfinancial performance evaluation as significant area of strategic business management. Business: Theory and Practice, 18, 71-78.

Huijuan, L. (2015). Default Prediction Model for SME's: Evidence from UK Market Using Financial Ratios. International Journal of Business and Management, 10(2), 81-106.

https://doi.org/10.5539/ijbm.v10n2p81 
Karas, M., \& Režňáková, M. (2014). Possibilities for the application of a bankruptcy prediction model for measuring credit risk of a company. In $12^{\text {th }}$ International Conference Proceedings of Hradec Economic Days 2014. Hradec Králové, Czech Republic.

Korol, T. (2013). Early warning models against bankruptcy risk for Central European and Latin American enterprises. Economic Modelling, 31, 22-30. https://doi.org/10.1016/j.econmod.2012.11.017

Kuběnka, M. (2015). Predictive ability of the index of creditworthiness. In $7^{\text {th }}$ International Scientific Conference Finance and Performance of Firms in Science, Education and Practice. Zlín, Czech Republic.

Liang, L., \& Wu, D. (2005). An application of pattern recognition on scoring Chinese corporations financial conditions based on backpropagation neural network. Computers and Operation Research, 32(5), 1115-1129. https://doi.org/10.1016/j.cor.2003.09.015

Merkl-Davies, D. M., Brennan, N. M., \& McLeay, S. J. (2011). Impression management and retrospective sense-making in corporate narratives: A social psychology perspective. Accounting, Auditing \& Accountability Journal, 24(3), 315-344. https://doi.org/10.1108/09513571111124036

Mohelska, H., \& Sokolova, M. (2016). Smart, connected products change a company's business strategy orientation. Applied Economics, 48(47), 4502-4509. https://doi.org/10.1080/00036846.2016.1158924

Neumaierová, I. (2005). Index IN05. In $2^{\text {nd }}$ International Conference Proceedings of European Financial Systems. Brno, Czech Republic.

Neumaierová, I., \& Neumaier, I. (2002). Výkonnost a tržní hodnota firmy: Metody, ukazatele, využití v $\operatorname{praxi}\left(1^{\text {st }}\right.$ ed.). Praha: Grada Publishing.

Ohlson, J. A. (1980). Financial ratios and the probabilistic prediction of bankruptcy. Journal of Accounting Research, 18(1), 109-131. https://doi.org/10.2307/2490395

Pacakova, V., Pardelova, R., Sodomova, E., \& Soltes, E. (2003). Statistics for Economists. Bratislava: Iura Edition.

Pendharkar, P. C. (2005). A threshold varying artificial neural network approach for classification and its application to bankruptcy prediction problem. Computers and Operations Research, 32(10), 2561-2582. https://doi.org/10.1016/j.cor.2004.06.023

Rafiei, F. M., Manzari, S. M., \& Bostanian, S. (2011). Financial health prediction models using artificial neural networks, genetic algorithm and multivariate discriminant analysis: Iranian evidence. Expert Systems with Applications, 38(8), 10210-10217. https://doi.org/10.1016/j.eswa.2011.02.082

Slavíček, O., \& Kuběnka, M. (2016). Bankruptcy prediction models based on the logistic regression for companies in the Czech Republic. In $8^{\text {th }}$ International Scientific Conference Proceedings Managing and Modelling of Financial Risks. Ostrava, Czech Republic.

Smith, R., \& Winakor, A. (1935). Changes in financial structure of unsuccessful industrial corporations. Bureau of Business Research (Bulletin 51). Urbana: University of Illinois Press.

Tam, K. (1991). Neural network models and the prediction of bank bankruptcy. Omega, 19(5), 429-445. https://doi.org/10.1016/0305-0483(91)90060-7

Tam, K., \& Kiang, M. (1992). Managerial applications of neural networks: The case of bank failure prediction. Management Science, 38(7), 926-947. https://doi.org/10.1287/mnsc.38.7.926

Zavgren, C. V. (1985). Assessing the vulnerability to failure of American industrial firm: A logistic analysis. Journal of Business Finance and Accounting, 12(1), 19-45. https://doi.org/10.1111/j.1468-5957.1985.tb00077.x

Zizlavsky, O. (2016). The Use of financial and nonfinancial measures within innovation management control: Experience and research. Economics \& Sociology, 9(4), 41-63.

https://doi.org/10.14254/2071-789X.2016/9-4/3 